УДК: 339.1

JEL: M30; M31

Sh. Sh. Sharapudinov ${ }^{1}$, V. V. Zezerova ${ }^{1}$, M. A. Storchevoy ${ }^{2}$

\title{
DETERMINANTS OF ONLINE WORD-OF-MOUTH: EVIDENCE FROM DURABLE GOODS MARKET
}

${ }^{1}$ National Research University Higher School of Economics, Russian Federation, 101000, Moscow, 20, Myasnitskaya ul.

${ }^{2}$ St. Petersburg State University, 7/9, Universitetskaya nab., St. Petersburg, 199034, Russian Federation

Online reviews have become one of the most effective tools to influence consumer behavior and level of sales. In this paper we consider determinants of online reviews and ratings. The study is based on more than three thousand online reviews from Russian consumers of durable goods (electronics and home appliances). We found a significant difference in the level of influence between new and old reviews. Moreover, the higher the total numbers of reviews available, the higher the number of reviews taken into account by a particular consumer. Another finding is that both average online rank and price of a product are positively correlated with variance of reviews about that product. Based on differences in the effectiveness of information transmission about quality, products were divided into two categories: experience goods and search goods. We provide an econometric model that helps explain not only the dynamic but also the direction of consumers' ranking of a product depending on the number and content of existing reviews.

Keywords: word-of-mouth marketing, online marketing, online reviews, search goods, experience goods, consumer behavior.

\section{ДИНАМИКА ОНЛАЙН-ОТЗЫВОВ НА РЫНКЕ ПОТРЕБИТЕЛЬСКИХ ТОВАРОВ ДЛИТЕЛЬНОГО ПОЛЬЗОВАНИЯ}

\author{
Ш. Ш. Шарапудинов ${ }^{1}$, В. В. Зезерова ${ }^{1}$, М. А. Сторчевой ${ }^{2}$ \\ ${ }^{1}$ Национальный исследовательский университет «Высшая школа экономики», \\ Российская Федерация, 101000, Москва, Мясницкая ул., 20 \\ ${ }^{2}$ Санкт-Петербургский государственный университет, Российская Федерация, 199034, \\ Санкт-Петербург, Университетская наб., 7/9
}

В настоящее время онлайн-отзывы стали одним из наиболее эффективных инструментов влияния на поведение пользователя и объем продаж. В статье анализируются характеристики более трех тысяч онлайн-отзывов российских пользователей на рынке электроники и бытовой техники. Установлено статистически значимое различие в степени влияния новых и старых отзывов на принятие решения написать свой отзыв, причем количество отзывов, принимаемых во внимание покупателем, растет с увеличением их общего числа. Также было выявлено положительное влияние среднего балла и цены товара на дисперсию оценок. Исходя из концепции разницы в эффективности передачи информации о качестве товара, товары были разделены на экспериментальные и поисковые блага. Далее предлагается эконометрическая модель, определяющая вероятность написания отзыва

Исследование финансировалось в рамках государственной поддержки ведущих университетов Российской Федерации "5-100". (The study has been funded by the Russian Academic Excellence Project "5-100".)

(c) Санкт-Петербургский государственный университет, 2017 
пользователем, а также его содержание в зависимости от количества и содержания отзывов, размещенных ранее.

Ключевые слова: маркетинг «из уст в уста», онлайн-маркетинг, онлайн-отзывы, поисковые блага, экспериментальные блага, поведение покупателя.

\section{INTRODUCTION}

Word-of-mouth marketing is one of the most effective sources of information about products and services, and has credibility among consumers [Гончарова, 2014; Reynolds, Beatty, 1999; Maxham, Netemeyer, 2002; Godes, Mayzlin, 2004; Nielsen Company, 2007]. The development of information technology significantly has enhanced possibilities for this communication channel to transform into eWOM - electronic wordof-mouth, which may be less personal but more effective. People with similar interests, needs, and preferences can share evaluations and exchange information regardless of their location or whether they even know each other. This feature of online communication is widely used in modern marketing: producers and sellers create online review systems to attract new customers. At present, the most popular online reviews systems are generated by users who have already tried a product or service and want to share their experiences.

The opportunity to learn other users' experiences in a convenient and interactive way without leaving one's home has made online reviews a powerful marketing tool. According to a study conducted by Deloitte Company, $81 \%$ of respondents actively read online reviews and check ratings to collect information about product, $57 \%$ read online forums, and $40 \%$ post their own reviews of products and services. At the same time, $60 \%$ of respondents name customer reviews as the most trusted source of information on products and services [The Growing Power..., 2014, p. 4, 5]. According to Nielsen Company, $71 \%$ of users trust consumer opinions posted online [Word-of-mouth recommendations..., 2015]. Positive relationships between online product ratings and sales volume emphasizes the marketing value of review systems [Godes, Mayzlin, 2004; Chevalier, Mayzlin, 2006]. Many publications reveal positive relationships between average product ratings and sales levels, which supports the practical importance of studying the dynamics of online reviews. Reviews raise awareness about the product and form an image of the product, which is why companies monitor the "average grade" of their products. While positive reviews can improve brand positioning and increase sales, negative reviews can weaken a brand's reputation and damage sales [Pfeffer, Zorbach, Carley, 2014].

Nevertheless, despite growing interest in online ratings, what factors affect the decision to write a review, and what factors affect the assessment of the product (besides immediate satisfaction), remain open questions. Even though the number of reviews positively influences awareness by future customers about the product, their estimates do not always converge, raising the question of the usefulness of online reviews for certain categories of products. When online reviews do not work well, the company needs to think about additional ways to inform users about its products. The main purpose of 
this study is to identify factors that influence dynamics of online reviews, reasons for writing reviews, and indicators that influence the probability of setting a certain rating.

The paper has the following structure. The first section provides a literature review for word-of-mouth marketing and online reviews to identify possible gaps in research. The second section contains descriptive statistics of online review data from an electronic durable goods website for eleven product categories, and from this we propose our hypotheses. The third and the fourth sections present empirical models that explain dynamics of online reviews for various categories of goods and try to predict the content of the next user's review. In conclusion, we summarize our findings and outline directions for further research.

\section{LITERATURE REVIEW}

Recommendations by friends and acquaintances and other forms of word-ofmouth have always been a popular channel for sharing opinions about products, and this can significantly influence consumer choice. In the Internet age, this channel has become more influential due to the speed of information transfer, as well as increased access to opinions of thousands people about a product. Consumers willingly share their experiences through various online platforms (online stores or aggregators such as Yandex.Market) and social networks. The variety of online channels of information exchange, wide audience coverage, and inessential time costs have made "word-ofmouth" marketing one of the more powerful tools for promoting products and services.

The most important role in this system is played by online reviews on websites for shops and trade platforms, which facilitate the accumulation, systematization, and generalization of customers' opinions of customers about purchased products and the quality of service. Literature devoted to online reviews can be divided into two main streams: 1) the impact of online reviews on future sales, and 2) consumer motivation in writing reviews.

Impact of online reviews on future sales. Research shows that there is a significant positive correlation between average product rating in online reviews (valency) and level of future sales in the e-book market [Chevalier, Mayzlin, 2006; Duan, $\mathrm{Gu}$, Whinston, 2008], in the film industry [Eliashberg, Shugan, 1997; Basuroy, Chatterjee, Ravid, 2003], in the video game market [Zhu, Zhang, 2010], in the beer market [Clemons, Gao, Hitt, 2006]. However, some economists still dispute such dependence [Duan, $\mathrm{Gu}$, Whinston, 2008]. Other authors [De Langhe, Fernbach, Lichtenstein 2015; Kozinets, 2016] argued that consumers trust average user ratings as indicators of objective product performance more than they should.

There is also disagreement over the comparative influence of positive and negative reviews. One of the most famous works on this topic is a comparative study of two online stores, Amazon.com and Barnesandnoble.com [Chevalier, Mayzlin, 2006]. Based on regression analysis of reviews for more than 3,000 books, the authors concluded that negative reviews have a more significant impact on sales than positive reviews. In addition, 
the authors found that users tend to give ratings higher than their real assessment. These findings were confirmed by a number of other studies that demonstrated how complaints and sharply negative reviews may reduce sales [Luo, 2007]. Negative reviews lead to a reduction in prices for products in highest price categories, while positive reviews only increase prices of cheap products [Chatterjee, 2001]. An increase in the number of comments and product ratings increases sales [Liu, 2006; Duan, Gu, Whinston, 2008; Forman, Ghose, Wiesenfeld, 2008].

In addition to valence and volume of online reviews, the third important factor affecting sales is the dispersion of online reviews. Research of the film market [Sun, 2012] and beer market [Clemons, Gao, Hitt, 2006] showed that ratings dispersion has a significant negative impact on sales, which means that sellers should try not only to increase the average rating, but also to control the dispersion of ratings.

Consumer motivation in writing a review. The second direction investigates motivation for writing online reviews. Early works on traditional word-of-mouth distinguished the following factors explaining a consumer's decision to write a review: deep interest in the product (brand loyalty, trend); the need for self-involvement (opportunity to gratify emotional needs connected with product usage); the necessity for discussion; altruism (helping without anticipating any reward, desire to share bad experiences to prevent people from using bad quality products or to advise people to avoid making bad choices about better-quality products); the desire to seek advice; and self-enhancement (opportunity to gain attention, suggest status, recommend oneself as an expert) [Dichter, 1966; Sundaram, Mitra, Webster, 1998].

A similar study for online reviews was first conducted by a group of German scholars [Hennig-Thurau et al., 2004]. Based on the survey of more than 2000 active users of systems with online reviews support and forums, the authors identified seven main motivations for participating in word-of-mouth, six of which coincide with the results of previous studies. Further, several other motives were highlighted, in particular, the desire to influence the quality of the product, because companies need to pay attention to uses' negative experiences.

According to [Ho, $\mathrm{Wu}, \mathrm{Tan}, 2014]$ the desire to write an online review depends not only on motives that arise after the purchase, but also on user's behavior before buying. The desire to write a review depends on the difference between expected quality of the product and what the buyer actually received (i.e. quality mismatch). When this difference is sufficiently high, the user decides to share his experience. Further, his rating depends on the difference between the observed average rating on the web-site and the user's own estimation of the product. This paper not only provides a theoretical basis for the hypotheses, but also builds an empirical model based on the method of ordinary least squares (OLS) and Monte Carlo method. Similar conclusions were obtained in other works [Anderson, Sullivan, 1993; Spreng, MacKenzie, Olshavsky, 1996; Hu, Liu, Zhang, 2008].

Some authors [Fu, Ju, Hsu, 2015] emphasize that intentions to engage in positive and negative online reviews are associated with different antecedents. Consumers who 
intend to post positive reviews are more driven by attitude, and consumers who consider posting negative reviews are more driven moral norms. Other authors [Balaji, Khong, Chong, 2016] focus mostly on decisions to write a negative review. On the basis of a selfreported retrospective survey of 206 online shoppers, the authors reveal the role of contextual, individual, and social networking factors in determining customers' intentions to engage in negative word-of-mouth communication. Another motive for participation is self-enhancement: users often write reviews knowingly controversial in relation to the average rating or last reviews, as a way to distinguish themselves from the general consensus [Hu, Liu, Zhang, 2008; Li, Hitt, 2008].

There is also a number of works that study factors influencing specific ratings. One paper [Gao, Gu, Lin 2006] based on an analysis of online reviews at CNET.com found that a user's rating depends positively on the average rating of all reviews, the last review for this product, and the expert's review; the influence of the expert's evaluation is more significant than the other two factors. An interesting result [Hu, Liu, Zhang, 2008], was that the influence of positive and negative reviews depends on the user's personal characteristics. The biggest impact is by reviews of users with a good expert reputation, as well as those who often write reviews in a given system. One paper [Aerts, Smits, Verlegh, 2017] investigates how the design of the online review platform may influence the content of the reviews.

However, recent works devoted to experts' reviews [Baber et al., 2016] argue that the average rating across all users tends to be more significant than experts' reviews. In addition, it is worth noting not only the influence of quantitative assessments, but also the content of reviews. One paper [Hennig-Thurau, Wiertz, Feldhaus, 2015] has shown that if there is only comment evaluation without quantitative ratings, users read negative comments more carefully, and so the influence of negative comments on purchasing decisions is higher. M. Salehan and D. J. Kim [Salehan, Kim, 2016] investigated predictors of readership and helpfulness of online consumer reviews using a sentiment mining approach for big data analytics. They found that reviews with higher levels of positive sentiment in the title receive more views. Sentimental reviews with neutral polarity in the text are also perceived to be more helpful. The length and longevity of a review positively influence both readership and helpfulness. The author suggested that online vendors should develop scalable automated systems for sorting and classifying big online review data, which would benefit both vendors and consumers. J. P. Singh and coauthors [Singh et al., 2017] also focused on the problem of handling a large number of online reviews, and they developed a model based on machine learning that can predict helpfulness of consumer reviews using several textual features, such as polarity, subjectivity, entropy, and reading ease. The model may automatically assign helpfulness values to an initial review as soon as it is posted on the website.

Quality and types of goods. An interesting direction of research focuses on the influence of online reviews for different types of goods. In the economics of information, there is a distinction between search goods and experience goods [Nelson, 1970; 1974]. Consumers can easily obtain information about the quality and utility of search goods 
before purchase (e.g. gasoline or paper). However, consumers can reveal the quality and subjective utility of experience goods only after buying and consuming them (e.g. a new phone model or a new book) [Hong, Chen, Hitt, 2014].

With development of Internet the cost of receiving information has radically changed, such that some authors suppose that the Internet has transformed some experience goods into search goods [Klein, 1998; Lynch, Ariely, 2000; Klein, Ford, 2003]. Since consumers can read online reviews of new books or phones, and also test some products online (e.g. software, games), this division between search goods and experience goods might be called into question. However, a series of empirical studies using a survey of Internet users indicates that there still exists a significant difference between these two types of goods [Thakor, Kumar, 2000; Krishnan, Hartline, 2001; Weathers, Makienko, 2006; Nakayama, Sutcliffe, Wan, 2010].

Online reviews as an instrument for evaluation were first used in [Hong, Chen, Hitt, 2014]. The authors argue that it is difficult to attribute goods to one or another type, and so it is more logical to consider each good as a combination of attributes (characteristics) of search and experience. Search attributes reflect the objective quality of goods, so information about them helps the buyer to get an idea of the product. Attributes of experience describe the subjective component of quality, therefore information about these characteristics is less useful for the buyer. Depending on which attributes prevail in the good, online reviews will have different effect on reduction of uncertainty about the quality of the good. For traditional search goods, an increase in the number of reviews leads to a convergence of estimates of online reviews, while for experience goods the dispersion of reviews increases. The number of online reviews positively correlates with dispersion of reviews for products with dominant attributes of experience, and negatively correlates with the spread of product ratings with dominant search attributes. Authors consider cumulative standard deviation as a measure of information diffusion effectiveness and a tool to distinguish search and experience goods. In the case of search goods, information transfer through online reviews should be effective, which is why we should see convergence of online reviews. "Convergence" is understood as a decrease in the cumulative standard deviation with an increase in number of reviews. In the case of experience goods, information exchange doesn't provide a very clear idea about the quality of a good, which is why the growth of online reviews should not cause a decrease in the variance of ratings, and with growth in the number of reviews, the cumulative standard deviation should not decrease.

Although experience goods bring greater uncertainty about the quality of the good, expressed in a large variance of estimates, if the user associates variation with differences in preferences, and not with the quality of the goods, this can serve as an additional incentive for risk lovers to buy the good [Evanston,, He, Bond, 2015]. Despite considerable interest in the topic, there are still open questions to consider. First, research is limited to a few segments, namely film and book markets. Second, almost all papers are focused on the influence of online reviews on sales, while consumer behavior in writing reviews is rarely studied. Third, extant research is limited to three main parameters of online 
reviews - average overall rating, number of reviews, and variance of reviews - while the impact of individual review characteristics is not considered. There is also a gap in understanding how previous reviews may influence the following variables: difference between new and old ratings, importance of user experiences, motives, impact of positive and negative reviews, textual information, support of the online community, and influence of the type of good on the decision to write a review. These factors seem to be significant for explaining the dynamics of online reviews, and so our study will focus on them.

Apart of variables that were not considered in previous papers, this research will also investigate motives for writing reviews and goods types as factors influencing dynamics of online reviews. Goods type and effectiveness of information transfer can also be factors underlying ratings formation. This paper investigates online reviews of Russian consumers in the electronic durable goods market. Since most extant research focuses on the American and Chinese markets, an analysis of Russian data is interesting for scholarly and practical perspectives. First, this paper will help us understand if there is empirical evidence for postulated motives based on users' behavior in the United States and China. Second, as stated in literature review, many research papers postulate the influence of average grade and dispersion on product sales. Thus, understanding those factors that influence its dynamic can play a crucial role for producers and resellers in positioning their product. Electronic durable goods are characterized by high activity of online reviews and has not been examined in previous research.

There are several studies of online reviews based on Russian data, but they address other aspects and do not resemble our research. For example, one paper [Полынская, 2014] explores customer satisfaction for a particular retail store based on Yandex.Market reviews. Another paper [Гимранов, 2017] uses Yandex.Market data to explore relationships between reviews and sales for electronic consumer goods, but it makes only general statements about positive links between number of reviews and sales volume. A third paper [Прохорова, 2017] conducted content analysis of reviews in Yandex.Market to distinguish various types of consumer experiences.

\section{DATA}

There are several large aggregators in the Russian online retail industry that provide information about product characteristics facilitate comparisons of prices, and accumulate online reviews. Yandex.Market ${ }^{1}$ is the most popular service for search and comparison of products in online retail stores. It has a rich database of online reviews, as well as detailed descriptions of product characteristics. The web-site is well structured and has a clear classification of product categories. The user can find not only the average score for a product, but also the distribution of evaluations. In addition to the quantitative evaluation, every review also has verbal comments divided into three fields: "Merits", "Shortcomings", and "Additional information". This structuring of feedback greatly

\footnotetext{
1 See: https://market.yandex.ru/
} 
simplifies the process of analyzing text variables, expanding possibilities for analysis of a product's quality satisfaction. Yandex.Market also provides detailed information about authors of reviews: it is possible to see user's name and the date of the review, the user's geographical location, and the user's activity on the platform expressed as the number of written reviews. No other aggregator provides such a range of information. Another important feature of this platform is the ability to track social acceptance: for each review there are "likes" and "dislikes". All these advantages indicate that this website is a good source for collecting data for empirical analysis.

We collected information from more than 3500 online reviews about consumer electronic products ${ }^{2}$. This information was coded into 22 variables described in Table 1.

Table 1. Variables

\begin{tabular}{|c|c|c|}
\hline Variable & Type & Description \\
\hline 1 & 2 & 3 \\
\hline Id & Quantitative & ID number \\
\hline product & Textual & Product name \\
\hline category & Categorial & Product category \\
\hline number_reviews & Quantitative & Number of product reviews for product \\
\hline sequence & Ordinal & Sequence of review for specific product \\
\hline average_grade & Quantitative & $\begin{array}{l}\text { Average rating before writing current review } \\
\text { (without rounding) }\end{array}$ \\
\hline avg_grade_round & Quantitative & $\begin{array}{l}\text { Average rating before writing current review } \\
\text { (rounded to } 0,5 \text { increments) }\end{array}$ \\
\hline total_grade & Quantitative & Total average rating (rounded) \\
\hline grade_word & Textual & Rating in comment (textual n comment) \\
\hline grade & Quantitative & Rating/grade by user \\
\hline author & Textual & Name of author \\
\hline author_n_reviews & Quantitative & Number of reviews written by current author \\
\hline
\end{tabular}

2 The authors are grateful to E. Pokryshevskaya for help in data collection. 
End of Table 1

\begin{tabular}{|c|c|c|}
\hline 1 & 2 & 3 \\
\hline experience1 & Dummy & Product use experience (less than month) \\
\hline experience 2 & Dummy & Product use experience (several months) \\
\hline experience3 & Dummy & Product use experience (more than year) \\
\hline ln_advan & Quantitative & $\begin{array}{l}\text { Logarithm of merit comment section length (in } \\
\text { symbols) }\end{array}$ \\
\hline ln_disadvan & Quantitative & $\begin{array}{l}\text { Logarithm of symbols number in shortcomings } \\
\text { comment section }\end{array}$ \\
\hline ln_comment & Quantitative & $\begin{array}{l}\text { Logarithm of symbols number in general } \\
\text { comment section }\end{array}$ \\
\hline likes & Quantitative & $\begin{array}{l}\text { Number of likes for current review, representing } \\
\text { the number of users who found the current } \\
\text { review informative or agreed with it }\end{array}$ \\
\hline dislikes & Quantitative & $\begin{array}{l}\text { Number of dislikes for current review, } \\
\text { representing the number users who did not find } \\
\text { the current review informative or did not agree } \\
\text { with it }\end{array}$ \\
\hline days & Quantitative & $\begin{array}{l}\text { Number of days between current and previous } \\
\text { review }\end{array}$ \\
\hline average_price & Quantitative & Average price of product \\
\hline min_price & Quantitative & Minimum price of product \\
\hline attributes & Quantitative & Number of product attributes \\
\hline
\end{tabular}

This analysis helps to formulate research hypotheses by identifying certain trends and deviations in the data. First, let us consider main aggregated metrics for online reviews for each product: average score and number of reviews among products.

As it is seen from the Table 2 , all products have an average score of 4 , with a difference of only 0,5 points between products. It is also worth noting that most of the values fall on positive ratings. This means that the products included in this study have good quality. 
Table 2. Descriptive statistics

\begin{tabular}{|l|c|c|c|c|c|}
\hline \multicolumn{1}{|c|}{ Variable } & Mean & Median & SD & Min & Max \\
\hline total_grade & 4,07 & 4,00 & 0,50 & 2 & 5 \\
\hline grade & 4,06 & 5,00 & 1,32 & 1 & 5 \\
\hline total_reviews & 276,74 & 191,00 & 244,48 & 30 & 854 \\
\hline
\end{tabular}

Data cover information about 60 products that are among the most discussed among electronic durable goods for Yandex.Market. They are divided into different categories based on product partition on the website (refrigerators, wash machines, TVs, etc.). The total list of categories is described in Table 3. If we consider all available reviews, the deviation from the average grade increases almost threefold at the level of individual categories. Despite a slight deviation in the average grade, the distribution of ratings within each product and between products is quite heterogeneous. In addition, if we consider the grade for products within each category, some categories are characterized by a stronger standard deviation in the rating values (about 1,8 points), while other categories are characterized by a weaker deviation $(0,6)$.

Table 3. Descriptive statistics by categories

\begin{tabular}{|l|c|c|c|c|c|c|}
\hline \multicolumn{1}{|c|}{ Category } & Mean & SD & Min & Max & Skewness & Kurtosis \\
\hline 1 & 2 & 3 & 4 & 5 & 6 & 7 \\
\hline GPS_navigator & 3,226563 & 1,670564 & 1 & 5 & $-0,260081$ & 1,400551 \\
\hline TV_set & 4,087838 & 1,222961 & 1 & 5 & $-1,242820$ & 3,428682 \\
\hline air_conditioner & 3,824074 & 1,490335 & 1 & 5 & $-0,972872$ & 2,415817 \\
\hline blender & 3,800643 & 1,523620 & 1 & 5 & $-0,817709$ & 2,062254 \\
\hline camera & 4,609012 & 0,783587 & 1 & 5 & $-2,552539$ & 10,182430 \\
\hline electr_book & 4,093333 & 1,328222 & 1 & 5 & $-1,325753$ & 3,405811 \\
\hline flatiron & 4,096070 & 1,242321 & 1 & 5 & $-1,200412$ & 3,254405 \\
\hline
\end{tabular}


End of Table 3

\begin{tabular}{|l|c|c|c|c|c|c|}
\hline \multicolumn{1}{|c|}{1} & 2 & 3 & 4 & 5 & 6 & 7 \\
\hline haircutting & 4,478261 & 1,172790 & 1 & 5 & $-2,222873$ & 6,492485 \\
\hline hairdrier & 3,902857 & 1,329049 & 1 & 5 & $-0,911510$ & 2,496006 \\
\hline kettle & 3,862069 & 1,396372 & 1 & 5 & $-0,915068$ & 2,440798 \\
\hline laptop & 4,270270 & 1,090980 & 1 & 5 & $-1,591336$ & 4,804533 \\
\hline memory_card & 3,034014 & 1,765014 & 1 & 5 & $-0,029270$ & 1,235737 \\
\hline playstation & 4,503006 & 0,955586 & 1 & 5 & $-2,268366$ & 7,769983 \\
\hline printer & 3,860606 & 1,422344 & 1 & 5 & $-0,933891$ & 2,435902 \\
\hline refrigerator & 4,156250 & 1,196226 & 1 & 5 & $-1,296717$ & 3,634723 \\
\hline screen & 4,337209 & 1,088058 & 1 & 5 & $-1,709219$ & 5,036268 \\
\hline smartphone & 4,075791 & 1,253139 & 1 & 5 & $-1,271245$ & 3,480383 \\
\hline vacuum_cleaner & 3,666667 & 1,512181 & 1 & 5 & $-0,719093$ & 1,981687 \\
\hline video_camera & 4,819820 & 0,575219 & 1 & 5 & $-4,302837$ & 24,480990 \\
\hline wash_mashine & 3,670330 & 1,426311 & 1 & 5 & $-0,712754$ & 2,112099 \\
\hline
\end{tabular}

Given that distribution of grades differs dramatically within categories, while average category scores are practically the same, one can ask about factors that influence the deviation of an individual user's rating, and whether reviews for a product converge in ratings.

In this paper we analyzed the convergence of ratings using the concept of search and experience goods. When online reviews converge, it may be said that this is a search good, and when they diverge, this is an experience good. The number of written reviews is provided in Table 2 . On average, about 277 reviews are written for each product, but the median is significantly different from the average, indicating that most products have more than the average number of reviews. Products are characterized as well by high deviation in number of reviews: there is a maximum of 854 reviews for one product.

Despite the fact that each product has a long history of ratings, it is logical to assume that users do not look through all comments, but read only the most recent 
and base purchasing decisions on these. In addition, the number of reviews taken into consideration may also depend on the length of the reviews' history.

Hypothesis H1. New ratings have a bigger impact on the user's current review than older ones: the higher the variance of previous reviews, the higher the deviation of the current rating from the average accumulated score.

To reflect the influence of price factors on the variance of reviews, information was collected not only about the average, but also about the minimum price, since for many users this can be a better predictor. Table 4 shows that products included in the study cover a broad price range: the standard deviation is around 10370 rubles, with the price of some products reaching 85515 rubles.

Table 4. Descriptive statistics

\begin{tabular}{|l|c|c|c|c|c|}
\hline \multicolumn{1}{|c|}{ Variable } & Mean & Median & SD & Min & Max \\
\hline average_price & 11125,99 & 7517,00 & 10371,91 & 532 & 85515 \\
\hline min_price & 9250,068 & 7490,00 & 6950,85 & 218 & 48400 \\
\hline attributes & 31,803 & 23,00 & 21,20 & 3 & 108 \\
\hline
\end{tabular}

Despite noticeable differences between average and minimum prices, standard deviation, and maximum price, it should be noted that the median value for the two prices is almost the same, indicating that the biggest difference in two prices belongs to the higher price segment. In addition, we can assume that users who buy more expensive products pay more attention to learning from other users, so the strength of the price effect will differ for products of the highest and lowest price categories.

Hypothesis H2. Average and minimum prices have different power to influence the dynamics of online reviews.

Table 4 also shows the number of attributes each product has: we see that the standard deviation is rather high and the range of values very high. As discussed in the first chapter of [Hong, Chen, Hitt, 2014], the number of attributes can influence the complexity of information communication and be closely related to types of goods.

Hypothesis H3. Products differ in complexity of information communication efficiency about the quality of the product: one can distinguish search goods and experience goods by means of online reviews dynamic estimation.

Further, a descriptive analysis of individual characteristics of the reviews was investigated. Variables presented in Table 5 are of great interest, since they reflect the content of reviews. On average, an author writes eight reviews, but the median value is much lower. This might indicate that the average for this variable is highly overestimated 
due to abnormally high values. The maximum value in 179 reviews per one author seemed doubtful. Although it was not a mistake of data registration, we decided to test for outliers to avoid bias.

Table 5. Descriptive statistics of individual review

\begin{tabular}{|l|c|c|c|c|c|}
\hline \multicolumn{1}{|c|}{ Variable } & Mean & Median & SD & Min & Max \\
\hline authors_n_reviews & 7,91 & 3,00 & 12,00 & 2 & 179 \\
\hline advantages & 185,11 & 101,00 & 257,44 & 0 & 2021 \\
\hline disadvantages & 190,68 & 99,00 & 267,19 & 0 & 2006 \\
\hline comment & 380,62 & 261,00 & 398,19 & 0 & 2230 \\
\hline likes & 27,39 & 12,00 & 58,23 & 0 & 2214 \\
\hline dislikes & 13,93 & 5,00 & 53,71 & 0 & 2508 \\
\hline
\end{tabular}

Despite the fact that the majority of ratings are positive, we see that the average length of comments describing advantages and disadvantages of products is practically the same. The average length of a comment is about 280 characters and significantly exceeds the sections on advantages and disadvantages. In this section users usually share their general perception of usage, that is why it reflects the most subjective part of the product quality assessment. These variables indicate the degree of informative feedback, as well as the ratio of negative and positive impressions about the use of the product.

The last block of variables is represented by "likes" and "dislikes" of a review. On average, each individual review has 12 "likes" and 5 "dislikes", but for some reviews, these variables exceed 2000 votes, which greatly increases the significance and reliability of these reviews. Considering that, on average, a product has 277 reviews, the number of users voting "likes" and "dislikes" significantly exceeds the number of written comments. The ability to track the popularity of a review is a very useful option for consumers. Further, individual characteristics of past reviews can influence the process of generating new reviews. In addition, the rating should be influenced by the perception of the quality of the product, i.e. the type of good.

Hypothesis H4. The probability of each rating depends on the type of good and individual motives of the user.

All suggested hypotheses were based on descriptive analysis of data and the preceding literature review. In the next section we will present the empirical model designed to test these hypotheses. 


\section{THE EMPIRICAL MODEL}

To estimate the dynamics of online reviews, a variable "difference" was created to reflect the module of standard deviation of the user's assessment from the accumulated average rating for previous users. As the main goal of this research is to estimate factors influencing the dynamic of online reviews, we need a measure showing how each following review tends to differ from the overall average rate. If we find the deviation is growing, then the user tends to differ, raising the question as to why they would diverge from previous users. We would like to start with an estimation of hypothesis not tested in previous papers. Then we will proceed with an estimation of personal motives and types of goods on the review dynamic. As hypothesis $H 1$ states, one reason might be the stronger influence of new reviews. The impact of the new responses is reflected in the variable SD_new10, which is equal to the standard deviation of the ratings of the previous ten reviews. We selected ten as a threshold, because this is the number of reviews reflected on one page in the Yandex.Market. The variable SD_old10 contains the standard deviation of older reviews not included in the SD_new10 count. To account for the influence of the last 20 reviews, we introduced the variables SD_new20 and SD_old20 in the same way.

Table 6 shows that previous reviews influence the writing of new reviews: there is a positive influence of deviation from the average among previous users on each subsequent review. Additionally, newer reviews have a greater impact on current reviews than older ones. Even if this result seems intuitively obvious, it is nevertheless important. Since users rely more on the latest reviews, this fact may be used by companies to create a positive signal about the quality of the product by monitoring only the latest reviews.

Interestingly, the total number of written reviews affects the number of reviews that influence the current review. For example, for products with more than 200 reviews (a rounded median value), the threshold for the number of recent reviews that are significant increases: the user is guided by the last twenty reviews rather than the last ten reviews, which indicates that such products are characterized by a broader analysis of previous comments and that the user psychologically feels the pressure of the amount of information available.

Table 6 shows results of both OLS (Ordinary Least Squares model) and FE for product category (fixed effects) models. The main difference of the FE model is that it takes into consideration the panel structure of data. Thus, this model helps to address unobserved heterogeneity related to each product category characteristics constant over time and not included in the regression (quality, audience of usage).Thus, we add binary variable for each product category to control for differences in categories.

Yandex.Market not only offers the possibility to investigate quality of products and to read existing reviews, but it also works as a service for comparing prices between stores, so that for each product one can see the minimum, maximum, and average prices. We expect that the price category for a product can also be a factor influencing dynamics of reviews grades. One reasons lies in the explanation for motives. For example, for altruistic people we can expect more engagement in review activity for more expensive products, as risk 
grows with the increase of price. For more expensive products, we can also expect a larger gap between expected and received quality needed to push the user to share her experience. However, an important question stated in hypothesis $\mathrm{H} 2$ above is which price to use as determinant, as the user can observe the minimum and average prices across stores.

Table 6. Difference in influence between new and old reviews

\begin{tabular}{|c|c|c|c|c|}
\hline \multirow{2}{*}{ Variable } & \multicolumn{2}{|c|}{ n_reviews $<200$} & \multicolumn{2}{|c|}{ n_reviews $>200$} \\
\hline & OLS & FE & OLS & FE \\
\hline SD_new10 & $\begin{array}{c}0,217^{\star *} \\
(-0,008)\end{array}$ & $\begin{array}{c}0,131^{\star *} \\
(-0,006)\end{array}$ & & \\
\hline SD_old10 & $\begin{array}{c}0,182^{\star *} \\
(-0,012)\end{array}$ & $\begin{array}{c}0,063^{\star *} \\
(-0,007)\end{array}$ & & \\
\hline average_grade & $\begin{array}{l}-0,310^{* *} \\
(-0,009)\end{array}$ & $\begin{array}{l}-0,552^{\star *} \\
(-0,013)\end{array}$ & $\begin{array}{l}-0,371^{\star *} \\
(-0,009)\end{array}$ & $\begin{array}{l}-0,634^{\star *} \\
(-0,011)\end{array}$ \\
\hline lnaverage_price & $\begin{array}{l}-0,011^{\star *} \\
(-0,003)\end{array}$ & & $\begin{array}{l}-0,020^{* *} \\
(-0,002)\end{array}$ & \\
\hline SD_new20 & & & $\begin{array}{c}0,193^{\star *} \\
(-0,011)\end{array}$ & $\begin{array}{c}0,137^{\star *} \\
(-0,005)\end{array}$ \\
\hline SD_old 20 & & & $\begin{array}{c}0,104^{* *} \\
(-0,015)\end{array}$ & $\begin{array}{c}0,043^{* *} \\
(-0,005)\end{array}$ \\
\hline Constant & $\begin{array}{c}2,214^{* *} \\
(-0,047)\end{array}$ & $\begin{array}{c}3,333^{\star *} \\
(-0,061)\end{array}$ & $\begin{array}{c}2,634^{* *} \\
(-0,066)\end{array}$ & $\begin{array}{c}3,704^{* *} \\
(-0,053)\end{array}$ \\
\hline$N$ & 3674 & 3674 & 3613 & 3613 \\
\hline$p$ & $0,000^{* *}$ & $0,000^{\star *}$ & $0,000^{\star *}$ & $0,000^{\star *}$ \\
\hline$R^{2}$ & 0,737 & 0,536 & 0,873 & 0,723 \\
\hline $\mathrm{BIC}$ & $-2721,802$ & $-4842,761$ & $-6399,963$ & $-7761,820$ \\
\hline
\end{tabular}

Significance level: ${ }^{*}-p<0,1 ;{ }^{* *}-p<0,05 ;{ }^{* *}-p<0,01$.

$\mathrm{N}$ o t e: in brackets one can find Standard Errors (SE) of parameters.

In Appendix 1 can be found that the coefficient of the average price logarithm is higher than the coefficient for the minimum price logarithm. This means that the average price has a more significant effect on the size of current user's deviation.

In the final model of factors affecting online reviews, we added fixed effects for product categories. In Table 7 we present the results of factors for ratings dynamic for situations when there are less than 100 reviews. 
Table 7. OLS regression for dynamic of online reviews

\begin{tabular}{|c|c|c|}
\hline Variable & Coefficient & SE \\
\hline SD_new & $0,201^{\star * *}$ & $-0,008$ \\
\hline SD_old & $0,166^{\star * *}$ & $-0,012$ \\
\hline average_grade & $-0,319^{* * *}$ & $-0,009$ \\
\hline lnaverage_price & $0,100^{*}$ & $-0,060$ \\
\hline category $==$ GPS_navigator & $0,113^{\star \star *}$ & $-0,031$ \\
\hline category $==T V \_s e t$ & 0,023 & $-0,025$ \\
\hline category==air_conditioner & $0,118^{\star * *}$ & $-0,014$ \\
\hline category $==$ blender & $0,091^{\star * *}$ & $-0,015$ \\
\hline category $==$ camera & 0,023 & $-0,015$ \\
\hline category==electr_book & $0,118^{\star * *}$ & $-0,012$ \\
\hline category $==$ flatiron & $0,082^{* * *}$ & $-0,015$ \\
\hline category $==$ haircutting & $0,109^{* * *}$ & $-0,022$ \\
\hline category $==$ hairdrier & $0,086^{* * *}$ & $-0,016$ \\
\hline category $==$ kettle & $0,063^{* * *}$ & $-0,015$ \\
\hline category==laptop & $0,035^{\star * *}$ & $-0,013$ \\
\hline category==memory_card & 0,023 & $-0,027$ \\
\hline category $==$ playstation & $0,063^{* * *}$ & $-0,014$ \\
\hline category $==$ printer & $0,138^{\star * *}$ & $-0,012$ \\
\hline category $==$ refrigerator & $-0,067^{\star \star}$ & $-0,032$ \\
\hline category $==$ screen & $-0,078^{\star \star \star}$ & $-0,014$ \\
\hline category==vacuum_cleaner & $0,125^{\star * *}$ & $-0,012$ \\
\hline category $==$ video_camera & $-0,010$ & $-0,028$ \\
\hline Constant & $2,035^{\star * *}$ & $-0,070$ \\
\hline$N$ & \multicolumn{2}{|c|}{3674} \\
\hline$p$ & \multicolumn{2}{|c|}{$0,000^{* * *}$} \\
\hline$R^{2}$ & \multicolumn{2}{|c|}{0,765} \\
\hline $\mathrm{BIC}$ & \multicolumn{2}{|c|}{$-2989,852$} \\
\hline
\end{tabular}

Significance level: ${ }^{*}-p<0,1 ;{ }^{* *}-p<0,05 ;^{* * *}-p<0,01$. 
This model shows that the standard deviation of a current review's rating from the average is positively affected by variance of previous reviews: an increase in the standard deviation of the last 10 responses by 1 increases the module of deviation by 0,2 ; for older reviews this is 0,16 . In addition, as the average rating increases, this deviation decreases. Also, for an increase of $1 \%$ in the product price, the deviation increases by 0,001 points. For products with low prices this factor might not be significant, but for products in the high price category, it can play an important role. In addition, there are significant differences in dynamics of online reviews between product categories.

One explanation is the theory of effectiveness of information transfer and the division between search goods and experience goods. In addition, if we enter a sequence variable in our model, it turns to be statistically insignificant. This can also be explained by the different direction of the effect of this change for experience and search goods. To test hypothesis $H 3$ we used the methodology proposed by [Hong, Chen, Hitt, 2014]. All products differ in subjective and objective perception of quality by consumers; therefore, the main indicator of type of good is the convergence of estimates in time or its absence. If products do not differ too much by main characteristics, then we can talk about one type of good for one category level. To divide products into search and experience goods, we used a simple regression and looked at the coefficient for sequence:

for category level

for product level

$$
S D_{n i j}=\beta_{0}+\beta_{1} \text { sequence }_{n i j}+\beta_{2} I_{j} \text {, }
$$

$$
S D_{n i}=\beta_{0}+\beta_{1} \text { sequence }_{n i},
$$

where $S D_{n i j}$ reflects cumulative standard deviation for review of sequence $n$ of product $i$ in category j; sequence $e_{n i}$ is order in reviews history for review of sequence $n$ of product $i$ in category $j ; I_{j}$ stays for category $j$.

For search goods there should be convergence of estimates and perception of quality. For experience goods we should observe an increase in variance or the absence of any trend due to subjectivity of the perception of quality (see Appendix 2).

Based on the results of Table 7, the binary variable "good_type" was encoded, with a value of 1 for an experience good, and then used to identify differences between reviews. That experience goods are perceived more subjectively should be reflected in the number of individual review characteristics. For experience goods one can expect more detailed, longer reviews with a greater degree of involvement of the social response in the form of "likes" and "dislikes". A variable "vote" was created, reflecting the sum of "likes" and "dislikes" and popularity of reviews. To test this hypothesis that reviews for experience goods should have a large number of disagreements; we calculated the ratio of "dislikes" to "likes".

Table 8 shows that the type of good has a significant impact on key characteristics of a rating. For experience goods, one can expect comments that are 17\% longer. This suggests that comments for experience goods are deeper and more detailed, since the description of their quality is more complicated than for search goods. Similarly, the description of shortcomings of products is $30 \%$ lengthier. This can also be explained 
by the difficulty in communicating dissatisfaction with the quality of these kinds of goods. It is worth noting that there is a completely different trend in the "Advantage" section - this section is shorter for experience goods. The importance of the variable "vote" means that reviews of experience goods are voted for 35\% less often than reviews of search goods. The variable that reflects the ratio of "likes" and "dislikes" does not show a significant dependence on the type of good.

Table 8. Influence of product types on main individual characteristics

\begin{tabular}{|l|c|c|c|c|}
\hline Variable & In_comment & ln_advan & In_disadvan & Vote \\
\hline good_type & $\begin{array}{c}0,156^{* * *} \\
(0,029)\end{array}$ & $\begin{array}{c}-0,136^{* * *} \\
(0,029)\end{array}$ & $\begin{array}{c}0,258^{* * *} \\
(0,035)\end{array}$ & $\begin{array}{c}-0,305^{* * *} \\
(0,036)\end{array}$ \\
\hline Constant & $\begin{array}{c}5,415^{* * *} \\
(0,025)\end{array}$ & $\begin{array}{c}4,682^{* * *} \\
(0,024)\end{array}$ & $\begin{array}{c}4,340^{* * *} \\
(0,030)\end{array}$ & $\begin{array}{c}2,815^{* * *} \\
(0,031)\end{array}$ \\
\hline$N$ & 7015 & 7439 & 7212 & 7057 \\
\hline$p$ & $0,000^{* * *}$ & $0,000^{* * *}$ & $0,000^{* * *}$ & $0,000^{* * *}$ \\
\hline
\end{tabular}

Significance level: ${ }^{*}-p<0,1 ;{ }^{* *}-p<0,05 ;^{* * *}-p<0,01$.

To conclude, the type of good affects not only the dynamics of ratings in reviews, but also the "Comment" section. There is also a significant difference in the popularity of such reviews. It can be assumed that the type of good determines not only the dynamics of estimates, but also the length of comments and involvement in these reviews.

\section{MODEL OF PROBABILISTIC DISTRIBUTION OF ESTIMATES}

Previous models described how reviews deviate from each other and what factors influence this trend over time. With their help we checked hypotheses $H 1-H 3$ where we estimated dynamic of reviews reflected in its cumulative standard deviation. However, these models cannot predict the direction of this deviation, i.e. when a user is going to submit low or high ratings. In addition, the influence of characteristics of previous reviews was not considered. To take into account how individual characteristics of previous reviews influence the probability of certain ratings, as well as the possibility to identify individual user motives and to check hypothesis $H 4$, we applied a model of an ordered logit. The rating put by the user is a score from 1 to 5 , with each point having a verbal interpretation. However, the difference in the user's perception of these scores varies considerably. For example, the difference between the rating of 5 and 4 will be less critical for the user in choosing a product than the difference between 4 and 3. In addition, as noted in the first 
part of this paper, some studies emphasize difference in positive and negative reviews. To check the direction of influence, three models were built. Prefix l_before variables reflects parameters of the last review before current one. The results are given in Table 9.

Table 9. Ordered logit models for review's rating estimation

\begin{tabular}{|c|c|c|c|}
\hline Variable & Model 1 & Model 2 & Model 3 \\
\hline average_grade & $1,121^{\star * *}$ & $0,086^{* * *}$ & $0,087^{\star * *}$ \\
\hline 1_grade & $0,125^{\star * *}$ & $0,480^{\star \star \star}$ & $1,071^{\star * *}$ \\
\hline good_type & $-0,356^{\star * *}$ & $-0,333^{\star * *}$ & $-0,377^{\star * *}$ \\
\hline 1_grade_days & $-0,003^{\star * *}$ & & \\
\hline 1_grade ${ }^{*}$ l_sequence & $-0,003^{* *}$ & $-0,001^{\star * *}$ & $-0,001^{*}$ \\
\hline 1_grade ${ }^{\star}$ l_ln_likes & $-0,000$ & & \\
\hline 1_grade ${ }^{\star}$ _ln_dislikes & $0,014^{\star *}$ & $0,001^{\star *}$ & $0,001^{\star * *}$ \\
\hline SD & & $-1,449^{\star}$ & \\
\hline SD_new & & & $-0,183^{\star *}$ \\
\hline SD_old & & & $-0,086$ \\
\hline lnaverage_price & & & $1,077^{\star}$ \\
\hline cut1 & $2,277^{\star *}$ & $-1,993^{\star *}$ & $2,536^{* *}$ \\
\hline cut 2 & $2,977^{\star *}$ & $-1,300^{\star}$ & $3,230^{\star *}$ \\
\hline cut3 & $3,608^{\star *}$ & $-0,681$ & $3,824^{\star *}$ \\
\hline cut 4 & $4,593^{* *}$ & 0,296 & $4,763^{\star *}$ \\
\hline$N$ & 5981 & 7517 & 6501 \\
\hline chi2 & $773,810^{\star *}$ & $1003,092^{\star *}$ & $822,296^{\star *}$ \\
\hline $\mathrm{BIC}$ & 14148,212 & 17898,010 & 15830,130 \\
\hline
\end{tabular}

Significance level: ${ }^{*}-p<0,1 ;^{* *}-p<0,05 ;^{* * *}-p<0,01$.

N o t e s: average_grade stays for the average rating for the product before current review; 1 grade rating of the previous user; good_type - binary variable that takes the value 1 for experience goods; 1_grade_days - number of days between current and previous reviews; SD - standard deviation of all previous reviews; SD_new - standard deviation of last 10 reviews; SD_old — standard deviation of all reviews written earlier than the last ten reviews; lnaverage_price - logarithm of average price of product. The next variables are cross-products and show how the influence of previous grade can change when controlling for its sequence in the review chain, its popularity, and level 1_grade ${ }^{\star}$ __sequence - change of influence of last grade based on its sequence number; 1 grade ${ }^{*} \_$_n_likes — change of influence of last grade based on how many users supported it by likes; 1 _grade ${ }^{\star}$ _ln_ldislikes — change of influence of last grade based on how many users disagreed with the previous users in the form of dislikes. 
Due to the specific nature of the ordered logit model, these coefficients cannot be directly interpreted, while conclusions can be made about the direction of influence.

Model 1 attempts to identify the effect of individual characteristics of previous reviews on the current rating, and to check the existence of the self-enhancement motive for users in the Russian market. The influence of a previous user's experience, her review history, the content of the user's comment, the number of positive and negative votes for the review, and the number of days between reviews were investigated. The model helped reveal a number of interesting patterns that contradict conclusions of some studies. This comparison is presented in Table 10.

Table 10. Investigation of individual motives

\begin{tabular}{|c|c|c|}
\hline Criterion & This paper & Previous papers \\
\hline $\begin{array}{l}\text { Relationship between } \\
\text { current rating and } \\
\text { average overall rating } \\
\text { of previous reviews }\end{array}$ & $\begin{array}{l}\text { Positive relationship: the higher the } \\
\text { current average grade, the higher } \\
\text { the probability that the next user } \\
\text { will give a higher rating; users are } \\
\text { guided by the desire to share good } \\
\text { impressions }\end{array}$ & $\begin{array}{l}\text { Negative relationship between the } \\
\text { prevailing opinion about a product } \\
\text { among previous users and the } \\
\text { current user [Li, Hitt, 2008] }\end{array}$ \\
\hline $\begin{array}{l}\text { Relationship between } \\
\text { last rating and current } \\
\text { rating }\end{array}$ & $\begin{array}{l}\text { A user tends to put a higher rating } \\
\text { than the previous user }\end{array}$ & $\begin{array}{l}\text { Users tend to distinguish } \\
\text { themselves from the crowd } \\
\text { by giving very negative rating } \\
\text { [Hu, Liu, Zhang, 2008] }\end{array}$ \\
\hline $\begin{array}{l}\text { Relationship between } \\
\text { frequency of reviews } \\
\text { and likelihood of a } \\
\text { maximum rating }\end{array}$ & $\begin{array}{l}\text { There is a negative correlation } \\
\text { between the number of days between } \\
\text { two reviews and the probability of } \\
\text { giving a higher rating }\end{array}$ & $\begin{array}{l}\text { The more days after the last review, } \\
\text { the more likely the next review } \\
\text { will contradict the last [Duan, Gu, } \\
\text { Whinston, 2008] }\end{array}$ \\
\hline $\begin{array}{l}\text { Relationship between } \\
\text { number of reviews and } \\
\text { new rating }\end{array}$ & $\begin{array}{l}\text { With the increase in number } \\
\text { of reviews, users are more likely } \\
\text { to submit a lower rating than the } \\
\text { previous user }\end{array}$ & $\begin{array}{l}\text { With a sufficiently large number } \\
\text { of reviews, users tend to write only } \\
\text { in case of negative experience [Hu, } \\
\text { Liu, Zhang, 2008] }\end{array}$ \\
\hline $\begin{array}{l}\text { Relationship between } \\
\text { expert's rating and } \\
\text { current rating }\end{array}$ & $\begin{array}{l}\text { Previous user's experience with } \\
\text { the usage of a product (as well as } \\
\text { number of reviews written) is not } \\
\text { a statistically significant factor } \\
\text { affecting the probability to giving } \\
\text { an exact rating }\end{array}$ & $\begin{array}{l}\text { Ratings of more experienced users } \\
\text { have a greater impact on ratings } \\
\text { given by the user than general } \\
\text { reviews [Gao, Gu, Lin, 2006] }\end{array}$ \\
\hline $\begin{array}{l}\text { Relationship between } \\
\text { length of previous } \\
\text { review and the next } \\
\text { evaluation }\end{array}$ & $\begin{array}{l}\text { Possible dependence between the } \\
\text { comment length of the previous } \\
\text { user, which reflects how informative } \\
\text { the review was, and the rating of } \\
\text { the following user. No statistically } \\
\text { significant dependence was found }\end{array}$ & $\begin{array}{l}\text { The lengthier the comment, } \\
\text { the more likely that evaluation is } \\
\text { negative [Hu, Liu, Zhang, 2008] }\end{array}$ \\
\hline
\end{tabular}


It is also worth noting that the influence of "dislikes" was statistically significant. The next review tends to be better than the previous one if the latter has many dislikes. This suggests that the user may explain unpopularity of the previous comment by its low evaluation and try to improve the rating of the product by a more positive review. (This is typical for users of the US and Chinese markets.) The type of good was statistically significant. This means that products with a higher degree of subjectivity in quality perception usually have lower scores.

Models 2 and 3 reflect the difference in the variation effect. New reviews have a more significant impact on users' decisions than the variance of old reviews for a product, and it is better to consider only variation in the most recent reviews' instead of aggregate variation of all reviews, as most papers usually stress.

Model 3 is our final model, with an application of price effects. When the price of a product increases, we expect an increase in the likelihood of a positive rating. Since for most categories, prices within a category do not differ significantly, it can be said that this positive effect is related to users' psychological characteristics. When buying expensive products, users are less likely to admit that a product is of poor quality [Tatzel, 2003]. Another explanation is that users are more attentive to choice for more expensive products.

Marginal effects reflect the change of probability of falling into a certain category as the variable increases by one. Results for Model 3 are shown in Table 11. Each column shows the corresponding grade that can be put by a user for a product. The table shows how increase by 1 of each of variables from the first column changes probability to put a grade in the review.

Table 11. Marginal effects

\begin{tabular}{|l|c|c|c|c|c|}
\hline \multicolumn{1}{|c|}{ Variable } & $\mathbf{1}$ & $\mathbf{2}$ & $\mathbf{3}$ & $\mathbf{4}$ & $\mathbf{5}$ \\
\hline 1_grade & $-0,006586$ & $-0,004668$ & $-0,004885$ & $-0,005461$ & 0,021600 \\
\hline average_grade & $-0,080982$ & $-0,057395$ & $-0,060067$ & $-0,067144$ & 0,265589 \\
\hline good_type & 0,028557 & 0,020240 & 0,021182 & 0,023678 & $-0,093656$ \\
\hline 1_gradel_1_dislikes & $-0,000070$ & $-0,000050$ & $-0,000052$ & $-0,000058$ & 0,000230 \\
\hline SD_new & 0,013880 & 0,009837 & 0,010295 & 0,011508 & $-0,045521$ \\
\hline 1_gradel_sequence & 0,000006 & 0,000004 & 0,000005 & 0,000005 & $-0,000021$ \\
\hline ln_average_price & $-0,005614$ & $-0,003979$ & $-0,004164$ & $-0,004655$ & 0,018411 \\
\hline
\end{tabular}


When the average rating increases by 1 unit, the probability of the next rating being "excellent" increases by $26,5 \%$. Among other significant factors that increase the likelihood of a positive evaluation, the logarithm of the price of products and evaluation of the last user are important.

One factor negatively influencing the probability of a positive rating is if the good is an experience good. The difficulty of assessing quality before buying it reduces the likelihood if giving a maximum rating by $9 \%$. This conclusion is important for sellers of experience goods. As was noted in the literature overview, there is a positive relationship between average rating and sales volume, as well as between the share of positive reviews and the popularity of the product. Consequently, sellers may be interested in reducing the effect of the good type on the likelihood of receiving low ratings. Since the type of good is associated with the lack of convergence in users' opinions, this indicates that online reviews are not an effective tool for obtaining information about these products. To increase users' level of awareness about such products, it is necessary to communicate information about product in another way: free demonstrations of product functionality and operation, opportunity to try the product in the store, and so on. It is also possible to make video reviews of products and place them on the same sites as extra information about products. Even if such reviews can be found on the Internet, they are not always made by experienced people. Product surveys posted on special sites, where there are both user reviews and product descriptions, might have a greater impact.

In addition, the positive attitude of users identified for the Russian market and absence of self-enhancement motive postulated for other countries can also be taken into account by sellers for marketing strategies.

\section{CONCLUSION}

This work has explored the dynamics of online reviews for the Russian electronics market. Although other researchers focused on the impact of aggregated online ratings on sales, we decided to identify factors that influence decisions to write an online review. We built an empirical model to assess factors that affect the size of the current user's deviation from the average rating. We show that there is a difference in influence between old and new ratings on subsequent ones. In particular, an increase in the standard deviation between users of the last ten reviews causes an increase of deviation for the current review. Products with a long history of reviews are characterized by deeper reviews search of current user and the number of more significant reviews increases. This can be taken into account by a company which receives negative feedbacks on the site and tries to correctly determine the number of positive feedback to create a positive image.

This research also shows significant difference in the influence of average and minimum prices: average price better explains rating dynamics. Significant differences in cumulative standard deviation are also related to the type of good. The influence of the type of good was examined for durable electronic products. Categories of search 
goods were characterized by convergence of reviews ratings, and online reviews form a correct perception of product quality. For experience good, sellers need to look for other ways to promote their products, so that buyers can directly try and examine a product before buying it. Here the good type not only influences rating dynamics, but also impacts users' activity in voting and showing their level of agreement, as well as size and depth of comments and reviews.

The last part of the study investigates the influence of individual characteristics of previous reviews, as well as motives for writing a review. The empirical analysis shows that even if a many papers postulate the significance of individual characteristics, most cannot predict the rating of the next user. We have found that for Russian users, it is not typical to write a review with an assessment in opposition to the previous comment. On the contrary, there is a statistically significant tendency to write more positive reviews than the average for previous users. There is also a positive relationship between the previous user's rating and the probability that the next user will give a higher grade.

One possible direction for further research is to investigate foreign online markets such as Ebay.com and Aliexpress.com as they become more popular among Russian consumers. For such platforms online reviews are almost the only way to learn about a product or sellers.

\section{References}

Гимранов Г. А. 2017. Влияние интернет-агрегаторов пользовательских отзывов на потребительский выбор. Экономика и управление (1): 129-133.

Гончарова И. В. 2014. Маркетинг «из уст в уста» в современных условиях развития информационных технологий и его использование в продвижении бренда. Вестник Воронежского государственного университета. Серия: Экономика и управление (4): 156-161.

Полынская Г. А. 2014. Сравнение методов оценки удовлетворенности потребителей при использовании разных способов сбора данных. Управление экономическими системами: электронный научный журнал 12 (72).

Прохорова Т. Б. 2017. Анализ клиентского опыта в отзывах покупателей интернет-магазинов России. Маркетинг в России и за рубежом (1): 69-77.

Aerts G., Smits T., Verlegh P. 2017. The platform shapes the message: How website design affects abstraction and valence of online consumer reviews. Decision Support Systems 104 (December): $104-112$.

Anderson E. W., Sullivan M. W. 1993. The antecedents and consequences of customer satisfaction for firms. Marketing science 12 (2): 125-143.

Baber A., Thurasamy R., Malik M. I., Sadiq B., Islam S., Sajjad M. 2016. Online word-of-mouth antecedents, attitude and intention-to-purchase electronic products in Pakistan. Telematics and Informatics 33 (2): 388-400.

Balaji M. S., Khong K. W., Chong A. Y. L. 2016. Determinants of negative word-of-mouth communication using social networking sites. Information \& Management 53 (4): 528-540.

Basuroy S., Chatterjee S., Ravid S. A. 2003. How critical are critical reviews? The box office effects of film critics, star power, and budgets. Journal of Marketing 67 (4): 103-117.

Chatterjee P. 2001. Online reviews: Do consumers use them? In: M. C. Gilly, J. Myers-Levy (eds.). Association for Consumer Research Proceedings; 129-134. URL: https://ssrn.com/abstract=900158 (accessed: 10.09.2017). 
Chevalier J. A., Mayzlin D. 2006. The effect of word of mouth on sales: Online book reviews. Journal of Marketing Research 43 (3): 345-354.

Clemons E. K., Gao G. G., Hitt L. M. 2006. When online reviews meet hyperdifferentiation: A study of the craft beer industry. Journal of Management Information Systems 23 (2): 149-171.

De Langhe, B., Fernbach P. M., Lichtenstein D. R. 2015. Navigating by the stars: Investigating the actual and perceived validity of online user ratings. Journal of Consumer Research 42 (6): 817-833.

Dichter E. 1966. How word-of-mouth advertising works. Harvard Business Review 44 (6): 147-160.

Duan W., Gu B., Whinston A. B. 2008. Do online reviews matter? - An empirical investigation of panel data. Decision Support Systems 45 (4): 1007-1016.

Eliashberg J., Shugan S. M. 1997. Film critics: Influencers or predictors? Journal of Marketing 61 (2): $68-78$.

Evanston I. L., He S. X., Bond S. D. 2015. Why is the crowd divided? Attribution for dispersion in online word of mouth. Journal of Consumer Research 41 (6): 1509-1527.

Forman C., Ghose A., Wiesenfeld B. 2008. Examining the relationship between reviews and sales: The role of reviewer identity disclosure in electronic markets. Information Systems Research 19 (3): 291-313.

Fu J. R., Ju P. H., Hsu C. W. 2015. Understanding why consumers engage in electronic word-of-mouth communication: Perspectives from theory of planned behavior and justice theory. Electronic Commerce Research and Applications 14 (6): 616-630.

Godes D., Mayzlin D. 2004. Using online conversations to study word-of-mouth communication. Marketing Science 23 (4): 545-560.

Gao G. G., Gu B., Lin M. 2006. The dynamics of online consumer reviews. Workshop on Information Systems and Economics (WISE), December 9-10, Northwestern University.

Hennig-Thurau T., Gwinner K. P., Walsh G., Gremler D. D. 2004. Electronic word-of-mouth via consumer-opinion platforms: What motivates consumers to articulate themselves on the Internet? Journal of Interactive Marketing 18 (1): 38-52.

Hennig-Thurau T., Wiertz C., Feldhaus F. 2015. Does Twitter matter? The impact of microblogging word of mouth on consumers' adoption of new movies. Journal of the Academy of Marketing Science 43 (3): 375-394.

Ho Y.-C., Wu J., Tan Y. 2014. Disconfirmation effect on online rating behavior: A dynamic analysis. SSRN Electronic Journal. 10,2139/ssrn,2516409.

Hong Y., Chen P. Y., Hitt L. 2014. Measuring Product Type with Dynamics of Online Product Review Variances: A Theoretical Model and the Empirical Applications. NET Institute, Working Paper No. 14-03. URL: https://ideas.repec.org/p/net/wpaper/1403.html (accessed: 10.09.2017).

Hu N., Liu L., Zhang J. J. 2008. Do online reviews affect product sales? The role of reviewer characteristics and temporal effects. Information Technology and Management 9 (3): 201-214.

Klein L. R. 1998. Evaluating the potential of interactive media through a new lens: Search versus experience goods. Journal of Business Research 41 (3): 195-203.

Klein L. R., Ford G. T. 2003. Consumer search for information in the digital age: An empirical study of prepurchase search for automobiles. Journal of Interactive Marketing 17 (3): 29-49.

Kozinets R. V. 2016. Amazonian forests and trees: Multiplicity and objectivity in studies of online consumer-generated ratings and reviews, a commentary on de Langhe, Fernbach, and Lichtenstein. Journal of Consumer Research 42 (6): 834-839.

Krishnan B. C., Hartline M. D. 2001. Brand equity: Is it more important in services? Journal of Services Marketing 15 (5): 328-342.

Li X., Hitt L. M. 2008. Self-selection and information role of online product reviews. Information Systems Research 19 (4): 456-474.

Liu Y. 2006. Word of mouth for movies: Its dynamics and impact on box office revenue. Journal of Marketing 70 (3): 74-89. 
Luo X. 2007. Consumer negative voice and firm-idiosyncratic stock returns. Journal of Marketing $7 \mathbf{1}$ (3): 75-88.

Lynch J. G. Jr., Ariely D. 2000. Wine online: Search costs affect competition on price, quality, and distribution. Marketing Science 19 (1): 83-103.

Maxham III J. G., Netemeyer R. G. 2002. A longitudinal study of complaining customers' evaluations of multiple service failures and recovery efforts. Journal of Marketing 66 (4): 57-71.

Nakayama M., Sutcliffe N., Wan Y. 2010. Has the web transformed experience goods into search goods? Electronic Markets 20 (3-4): 251-262.

Nelson P. 1970. Information and consumer behavior. Journal of Political Economy 78 (2): 311-329.

Nelson P. 1974. Advertising as information. Journal of Political Economy 82 (4): 729-754.

Pfeffer J., Zorbach T., Carley K. M. 2014. Understanding online firestorms: Negative word-of-mouth dynamics in social media networks. Journal of Marketing Communications 20 (1-2): 117-128.

Reynolds K. E., Beatty S. E. 1999. Customer benefits and company consequences of customersalesperson relationships in retailing. Journal of Retailing 75 (1): 11-32.

Salehan M., Kim D. J. 2016. Predicting the performance of online consumer reviews: A sentiment mining approach to big data analytics. Decision Support Systems 81: 30-40.

Singh J. P., Irani S., Rana N. P., Dwivedi Y. K., Saumya S., Roy P. K. 2017. Predicting the "helpfulness" of online consumer reviews. Journal of Business Research 70: 346-355.

Spreng R. A., MacKenzie S. B., Olshavsky R. W. 1996. A reexamination of the determinants of consumer satisfaction. Journal of Marketing 60 (3), 15-32.

Sun M. 2012. How Does the Variance of Product Ratings Matter? Management Science 58 (4): 696-707.

Sundaram D. S., Mitra K., Webster C. 1998. Word-of-mouth communications: A motivational analysis. Advances in Consumer Research 25 (1): 527-531.

Tatzel M. 2003. The art of buying: Coming to terms with money and materialism. Journal of Happiness Studies 4 (4): 405-435.

Thakor M. V., Kumar A. 2000. What is a professional service? A conceptual review and bi-national investigation. Journal of Services Marketing 14 (1): 63-82.

The Growing Power of Consumers. The Deloitte Consumer Review. 2014. URL: https://www2.deloitte. $\mathrm{com} /$ content/dam/Deloitte/uk/Documents/consumer-business/consumer-review-8-the-growing-power-of-consumers.pdf (accessed: 10.09.2017).

Weathers D., Makienko I. 2006. Assessing the relationships between e-tail success and product and web site factors. Journal of Interactive Marketing 20 (2): 41-54.

Word-of-mouth recommendations remain the most credible. 2015. Nielsen Company. URL: http:// www.nielsen.com/id/en/press-room/2015/WORD-OF-MOUTH-RECOMMENDATIONSREMAIN-THE-MOST-CREDIBLE.html (accessed: 10.09.2017).

Zhu F., Zhang X. 2010. Impact of online consumer reviews on sales: The moderating role of product and consumer characteristics. Journal of Marketing 74 (2): 133-148.

\section{The List of References in Cyrillic Transliterated into Latin Alphabet}

Gimranov G. A. 2017. Vliianie internet-agregatorov pol'zovatel'skikh otzyvov na potrebitel'skii vybor [Impact of online-aggregators of user feedback on consumer choice]. Ekonomika i upravlenie (1): 129-133.

Goncharova I. V. 2014. Marketing «iz ust v usta» v sovremennykh usloviiakh razvitiia informatsionnykh tekhnologii i ego ispol'zovanie v prodvizhenii Brenda [Markteing «by word of mouth» in modern conditions of development of information technologies and its use in advance of the brand]. Vestnik Voronezhskogo gosudarstvennogo universiteta. Seriia: Ekonomika i upravlenie (4): $156-161$.

Polynskaia G. A. 2014. Sravnenie metodov otsenki udovletvorennosti potrebitelei pri ispol'zovanii raznykh sposobov sbora dannykh [Comparison of methods for evaluation of customer 
satisfaction using different methods of data collection]. Upravlenie ekonomicheskimi sistemami: elektronnyi nauchnyi zhurnal 12 (72).

Prokhorova T. B. 2017. Analiz klientskogo opyta v otzyvakh pokupatelei internet-magazinov Rossii [Analysis of customer experience in customer reviews of online shops in Russia]. Marketing $v$ Rossii i za rubezhom (1): 69-77.

For citation: Sharapudinov Sh. Sh., Zezerova V. V., Storchevoy M. A. Determinants of Online Word-of-Mouth: Evidence from Durable Goods Market. Vestnik of Saint Petersburg University. Management, 2017, vol. 16, issue 4, pp. 622-650. https://doi.org/10.21638/11701/spbu08.2017.406.

Contact information

Sharapudinov Shamil Sh. - Research Fellow; ssharapudinov@hse.ru

Zezerova Viktoriia V. - PhD Student; vvzezerova@gmail.com

Storchevoy Maxim A. — PhD, Senior Lecturer; storchevoy@gsom.pu.ru 
Appendix 1

COMPARISON OF MINIMUM AND AVERAGE PRICES

\begin{tabular}{|c|c|c|}
\hline Variable & Model 1 & Model 2 \\
\hline SD_new & $\begin{array}{c}0,217^{* * *} \\
(-0,008)\end{array}$ & $\begin{array}{c}0,217^{\star * *} \\
(-0,008)\end{array}$ \\
\hline SD_old & $\begin{array}{c}0,182^{* * *} \\
(-0,012)\end{array}$ & $\begin{array}{c}0,183^{\text {***}} \\
(-0,012)\end{array}$ \\
\hline average_grade & $\begin{array}{l}-0,310^{* * *} \\
(-0,009)\end{array}$ & $\begin{array}{l}-0,312^{\star * *} \\
(-0,009)\end{array}$ \\
\hline lnaverage_price & $\begin{array}{l}-0,011^{\star * *} \\
(-0,003)\end{array}$ & \\
\hline lnmin_price & & $\begin{array}{l}-0,007^{\star *} \\
(-0,003)\end{array}$ \\
\hline Constant & $\begin{array}{c}2,214^{\star * *} \\
(-0,047)\end{array}$ & $\begin{array}{c}2,181^{\star * *} \\
(-0,046)\end{array}$ \\
\hline$N$ & 3674 & 3674 \\
\hline$p$ & $0,000^{* * *}$ & $0,000^{* * *}$ \\
\hline$R^{2}$ & 0,737 & 0,736 \\
\hline $\mathrm{BIC}$ & $-2721,816$ & $-2714,331$ \\
\hline
\end{tabular}

Significance level: ${ }^{*}-p<0,1 ;^{* *}-p<0,05{ }^{* * *}-p<0,01$. 
Appendix 2

GOODS TYPE RESEARCH

\begin{tabular}{|c|c|c|c|}
\hline \multirow{2}{*}{ Category } & \multicolumn{2}{|c|}{ Coefficient } & \multirow{2}{*}{ Classification } \\
\hline & OLS regression & FE regression & \\
\hline GPS devices & $\begin{array}{l}0,0075303^{* * *} \\
(0,0017885)\end{array}$ & $\begin{array}{l}0,0088878^{* * *} \\
(0,00126)\end{array}$ & Experience good \\
\hline TVs & $\begin{array}{l}0,0074633^{* * *} \\
(0,001573)\end{array}$ & $\begin{array}{l}0,0044616^{* * *} \\
(0,0016804)\end{array}$ & Experience good \\
\hline Air conditioners & $\begin{array}{l}0,0093726^{* * *} \\
(0,0014869)\end{array}$ & $\begin{array}{l}0,0096551^{* * *} \\
(0,0011025)\end{array}$ & Experience good \\
\hline Blenders & $\begin{array}{l}0,0075374^{* * *} \\
(0,0003625)\end{array}$ & $\begin{array}{l}0,0069316^{\star * *} \\
(0,000358)\end{array}$ & Experience good \\
\hline Cameras & $\begin{array}{l}-0,0007697^{* * *} \\
(0,000114)\end{array}$ & $\begin{array}{l}-0,0008705^{\star * *} \\
(0,000084)\end{array}$ & Search good \\
\hline E-books & $\begin{array}{l}0,0004272^{* * *} \\
(0,0002787)\end{array}$ & $\begin{array}{l}0,0016315^{\star * *} \\
(0,0000873)\end{array}$ & Experience good \\
\hline Iron & $\begin{array}{l}0,0053102^{* * *} \\
(0,0005395)\end{array}$ & $\begin{array}{l}0,0046685^{\star * *} \\
(0,0004358)\end{array}$ & Experience good \\
\hline Hair clippers & $\begin{array}{l}-0,0083088^{\star * *} \\
(0,0021145)\end{array}$ & $\begin{array}{l}-0,0038414^{\star * *} \\
(0,0014136)\end{array}$ & Search good \\
\hline Hair dryers & $\begin{array}{l}-0,0035524^{\star * *} \\
(0,0011499)\end{array}$ & $\begin{array}{c}0,001107 \\
(0,0007416)\end{array}$ & Search good \\
\hline Electric kettles & $\begin{array}{l}-0,0011884^{* * *} \\
(0,0001415)\end{array}$ & $\begin{array}{l}0,0001985^{\star *} \\
(0,0000849)\end{array}$ & $\begin{array}{l}\text { Need to check } \\
\text { on product level }\end{array}$ \\
\hline Memory cards & $\begin{array}{l}0,0048717^{\star} \\
(0,002001)\end{array}$ & $\begin{array}{l}0,0056614^{* * *} \\
(0,001538)\end{array}$ & Experience good \\
\hline
\end{tabular}


Sh. Sh. Sharapudinov, V. V. Zezerova, M. A. Storchevoy

\begin{tabular}{|c|c|c|c|}
\hline Video game consoles & $\begin{array}{l}-0,0009675^{* * *} \\
(0,000244)\end{array}$ & $\begin{array}{l}-0,0023711^{* * *} \\
(0,000104)\end{array}$ & Search good \\
\hline Printers & $\begin{array}{l}0,0041294^{* * *} \\
(0,0005495)\end{array}$ & $\begin{array}{l}0,0039732^{\star * *} \\
(0,0004002)\end{array}$ & Experience good \\
\hline Refrigerators & $\begin{array}{c}0,0018406 \\
(0,0016169)\end{array}$ & $\begin{array}{l}0,0043503^{* *} \\
(0,0015055)\end{array}$ & Experience good \\
\hline Mobile phone & $\begin{array}{l}0,0005597^{\star * *} \\
(0,0000152)\end{array}$ & $\begin{array}{l}0,0005972^{\star * *} \\
(0,0000108)\end{array}$ & Experience good \\
\hline Vacuum cleaners & $\begin{array}{l}0,0012967^{\star * *} \\
(0,000139)\end{array}$ & $\begin{array}{l}0,0008939^{\star * *} \\
(0,000071)\end{array}$ & Experience good \\
\hline Washing machines & $\begin{array}{l}0,0044766^{*} \\
(0,0017218)\end{array}$ & $\begin{array}{l}0,0027921^{* * *} \\
(0,000655)\end{array}$ & Experience good \\
\hline
\end{tabular}

Significance level: ${ }^{*}-p<0,05 ;{ }^{* *}-p<0,01 ;{ }^{* * *}-p<0,001$. 